\title{
THE FIRST RECORD AND THE BEGINNING THE SPREAD OF OAK LACE BUG, Corythucha arcuata (Say, 1832) (HETEROPTERA: TINGIDAE), IN SLOVENIA
}

\section{PRVI NALAZ I POČETAK ŠIRENJA HRASTOVE MREŽASTE STJENICE, Corythucha arcuata (Say, 1832) (HETEROPTERA: TINGIDAE), U SLOVENIJI}

Maja JURC' ${ }^{1}$ Dušan JURC²

\begin{abstract}
Summary
Here we report the discovery of Corythucha arcuata in Slovenia in autumn 2016. Egg shells and molts of oak lace bug were found on the fallen leaves of Quercus robur in an oak forest in the village of Zakot near Brežice in the southeastern part of Slovenia. C. arcuata most likely spread to Slovenia from Croatia, where it was previously reported from the park at Lužnica Castle near Zaprešić, $14 \mathrm{~km}$ from the find in Slovenia, or as a hitchhiker on rail traffic running along the northern edge of infested forest. Further spread of C. arcuata to Krakovo oak forest was detected in the beginning of July 2017.
\end{abstract}

KEY WORDS: invasive species, alien species, pedunculate oak, Quercus robur, Slovenia

\section{INTRODUCTION}

\section{UVOD}

Corythucha arcuata (Say, 1832) (Heteroptera: Tingidae) originates from North America and has a wide geographical range in the USA and Canada (Drake and Ruhoff, 1965; Rabitsch, 2008). The first incidence of the pest in Europe was recorded in Italy in May 2000 in one of the parks near Milan. It is known to be widely distributed throughout northern Italy, in the Lombardy and Piedmont regions (Bernardinelli and Zandigiacomo, 2000). It was found in southern Switzerland in 2002 (Forster et al., 2005) and in Turkey in 2003 (Mutun, 2003). Within just five years, the species spread to a large part of Turkey, including nine provinces (Mutun et al., 2009). In 2012 its presence was confirmed in a few localities close to transport routes or within towns in Bulgaria (Dobreva et al., 2013) and in 2013 in Hungary, where it was reported in a very small and localized population (Csóka et al., 2013). In 2013 C. arcuata was found in lowland stands of Quercus robur $\mathrm{L}$. in eastern Croatia (Hrašovec et al., 2013) and in Serbia, in the oak forests of Srem in Vojvodina (Pap et al., 2015).

The main hosts of oak lace bug are oaks belonging to the white oak group. A more detailed list of host plants is reported by Drake and Ruhoff (1965), Osborn and Drake (1917), Drew and Arnold (1997) and Dobreva et al. (2013), and includes Quercus muehlenbergii Engelm., Q. alba L., Q. macrocarpa Michx., Q. prinoides Willd., and Q. prinus L., Q. rubra L. as well as the leaves of the following genera: Castanea, Acer, Pyrus, Malus and Rosa. In Europe the hosts of C. arcuata are Quercus petraea (Matt.) Liebl, Q. robur L., Q. pubescens Willd., Q. cerris L., Q. rubra L., Rubus idaeus L., Castanea sativa Mill. and Rosa canina L. (Bernardinelli and Zandigiacomo,

\footnotetext{
'Prof. dr. sc. Maja Jurc (maja.jurc@bf.uni-lj.si); Biotechnical faculty, Department for Forestry and Renewable Forest Resources, University of Ljubljana

${ }^{2}$ Prof. dr. sc. Dušan Jurc (dusan.jurc@gozdis.si); Slovenian Forestry Institute, Department for Forest Protection, Ljubljana; Biotechnical faculty,

Department for Forestry and Renewable Forest Resources, University of Ljubljana
} 
2000; Mutun, 2003; Forster et al., 2005; Dioli et al., 2007; Mutun et al., 2009; Dobreva et al., 2013). It has occasionally been found on Rubus ulmifolius Schott, but fewer eggs are deposited on this host compared to Quercus spp. R. ulmifolius is used by C. arcuata as an overwintering site (Bernardinelli, 2006). In Croatia, besides the predominantly affected leaves of pedunculate oak, damage and tingid developmental stages were also found on European crab apple (Malus sylvestris /L./), Rubus spp. and, for the first time, the field elm (Ulmus minor Mill.) (Hrašovec et al., 2013).

In the northeastern states of the USA, where it is native, $C$. arcuata is known to complete two generations a year and have a partial third generation, with some adults from the second generation and those from the third overwintering (Connell and Beacher, 1947). In the warmer climate of Italy, it can complete three generations a year and have a partial fourth (Bernardinelli, 2000).

C. arcuata feeds directly on leaves, sucking fluid from the cells between the upper and lower epidermis of the leaves and causing discoloration of the upper leaf surface. This results in a reduction in photosynthesis and may cause premature leaf fall in heavy infestations. The pest may also increase the susceptibility of its host to other insects and diseases (Connell and Beacher, 1947).

\section{MATERIALS AND METHODS MATERIJALI I METODE}

Information on the discovery of oak lace bug in the park at Lužnica Castle near Zaprešić, Croatia, 6 kilometers from Slovenian border, was provided by prof. Boris Hrašovec from the Faculty of Forestry, University of Zagreb, Croatia in autumn 2016. On 17 November 2016 we performed a search for the pest on still attached and fallen leaves of Q. robur at the following locations in southeastern Slovenia: Mokrice Castle ( 5 trees of $Q$. robur), the village of Obrežje ( 2 trees), the village of Rigonce (1 tree), Dobova ( 3 trees), Mostec (3 trees), Zakot (oak forest), and Bukošek (oak forest). Partially green leaves attached to the branches and fallen leaves of $Q u$ ercus robur were carefully inspected for signs of oak lace bug and suspected samples were placed in plastic bags and brought to the laboratory for further study. In early July 2017 we visited a wider area of western Slovenia and searched for the symptoms and the presence of $C$. arcuata.

Morphological identification was performed on samples of egg clusters on the underside of leaves and larval molts (exuviae) that were present on the fallen leaves of $Q$. robur. The number of eggs in 9 clusters of eggs was counted and length and width of 30 eggs were measured. Photographs were taken and measurements performed using an Olympus SZX16 binoculars equipped with an Olympus UC90 digital camera and the cellSens program Standard and with Nikon D200 camera (AF-S MICRO NIKKOR 105mm 1:2.8G).

\section{RESULTS AND DISCUSSION} REZULTATI I RASPRAVA

In autumn 2016 the pest was found only at Zakot, a village near the town of Brežice, in a mature oak forest stand measuring $4,427 \mathrm{~m}^{2}$ (coordinates of the find: $15^{\circ} 36^{\prime} 47^{\prime \prime} \mathrm{E}$, $45^{\circ} 54^{\prime} 48^{\prime \prime} \mathrm{N}$ ), which is $14 \mathrm{~km}$ from the find in Croatia at the Lužnica Castle. Egg clusters and numerous larval exuviae were found on fallen leaves and not on those still attached to branches. The egg clusters contained from 12 to 61 empty eggs. Egg shells were spindle shaped and black with an apical opercular area with a rim. They were $560 \mu \mathrm{m}$ long ( $475-596$ $\mu \mathrm{m})$ and $196 \mu \mathrm{m}(183-196 \mu \mathrm{m})$ wide and generally corresponded to the measurements reported by Baker and Brown (1994), which were on average $583 \mu \mathrm{m}$ long and $206 \mu \mathrm{m}$ wide.

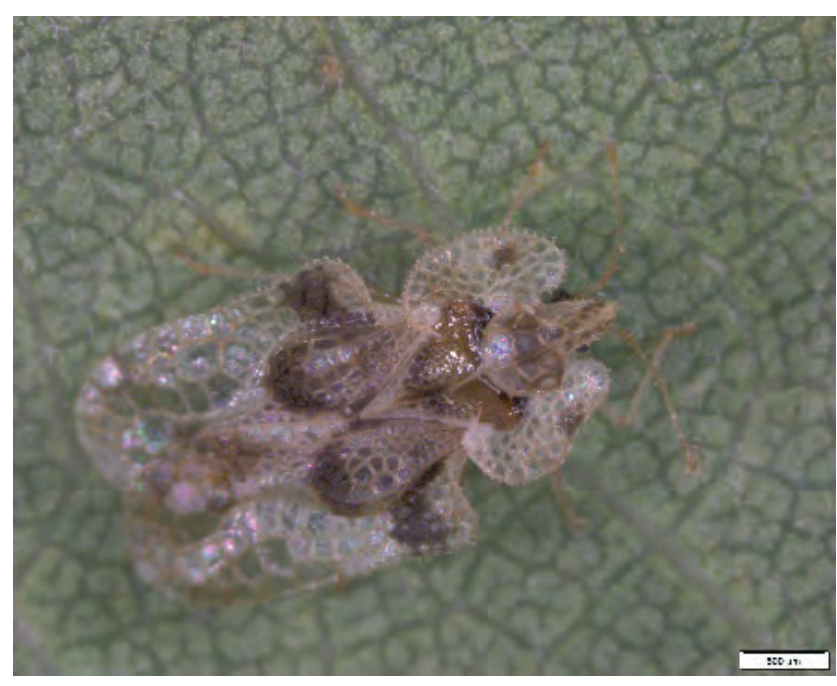

Figure 1. The oak lace bug (Corythucha arcuata), 11.7.2017, location Zakot

Slika 1. Hrastova mrežasta stjenica (Corythucha arcuata), 11.7.2017., lokacija Zakot

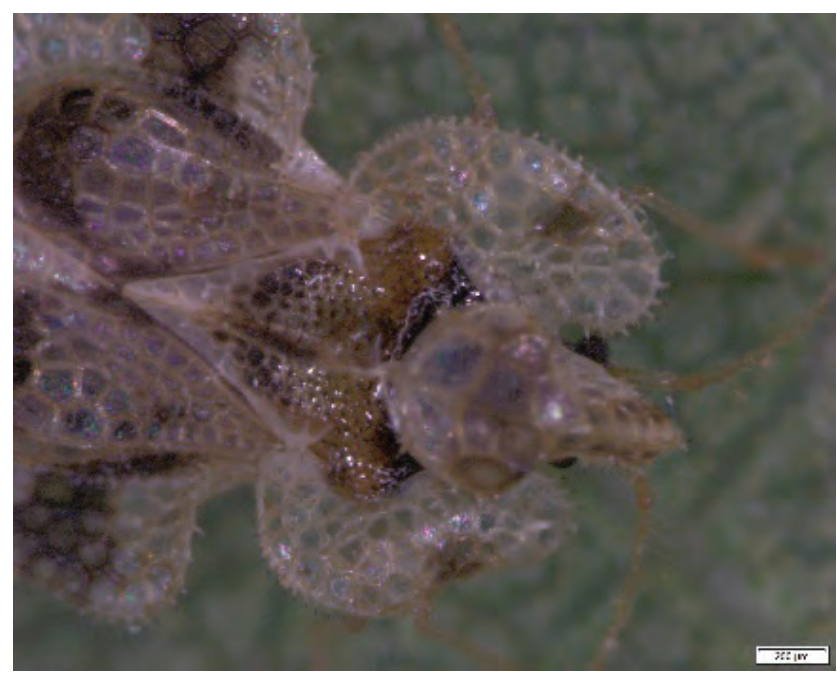

Figure 2. Detail of the head, C. arcuata, 11.7.2017, location Zakot Slika 2. Detalj glave, C. arcuata, 11.7.2017., lokacija Zakot 


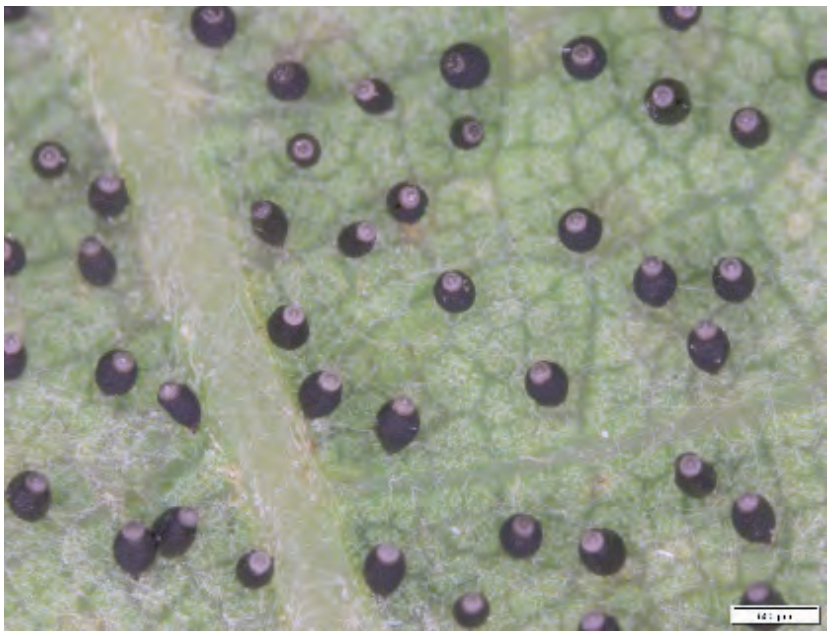

Figure 3. Cluster of eggs of oak lace bug on the underside of pedunculate oak leaves, 11.7.2017, location Zakot

Slika 3. Grupa jaja hrastove mrežaste stjenice na donjoj strani lista lužnjaka, 11.7.2017., lokacija Zakot

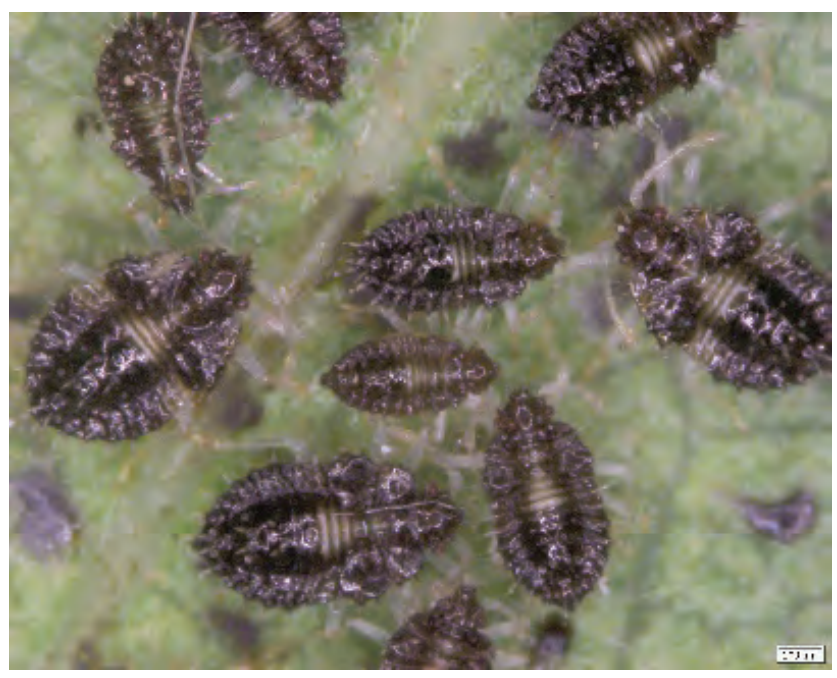

Figure 4. Nymphs were mostly dark with translucent yellowish parts on both sides and with spines, 11.7.2017, location Zakot

Slika 4. Ličinke su uglavnom tamne s prozirnim žućkastim dijelovima na obje strane tijela i sa bodljama, 11.7.2017. Iokacija Zakot

Nymph molts were mostly dark with translucent yellowish parts on both sides. They had numerous spines. Numerous tar-like black spots of bug excrement (faeces) were located evenly on the underside surface of oak leaves with larval molts and groups of eggs. The find and identification of the pest was reported to the NPPO of Slovenia on 30 November 2016. In July 2017 we found egg clusters, nymphs and adults of $C$. arcuata on oaks near village Zakot in large numbers and chlorosis on the leaves as a result of sucking. Wider search revealed small populations of oak lace bug on the edge of Krakovo oak forest, which is $17 \mathrm{~km}$ air distance from the first find at village Zakot (Figures 1-6).

The spread of C. arcuata in Croatia has been extremely rapid, most probably due to the main traffic corridors. Three years

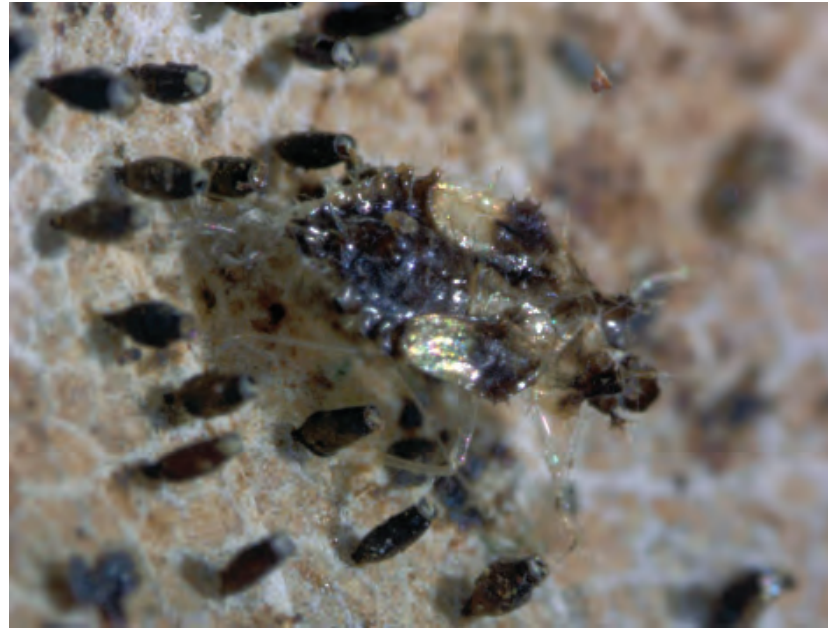

Figure 5. Egg shells and nymph molt on the underside of fallen oak leaves, 17.11.2016, location Zakot

Slika 5. Jajne čahure i svlak ličike na donjoj strani otpalog hrastovog lišća, 17.11.2016., lokacija Zakot

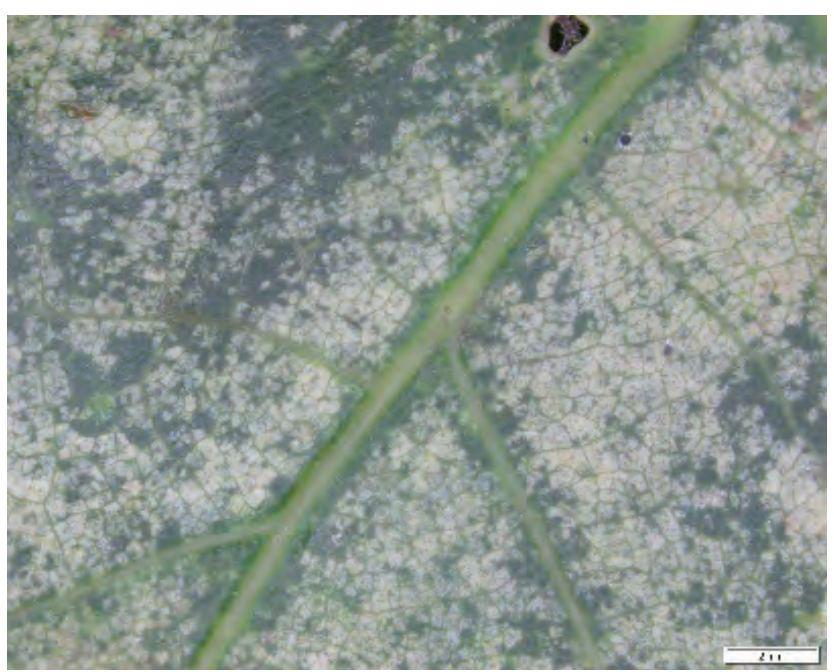

Figure 6. Chlorotic spots on the leaves as a result of sucking of adults and larvae of $C$. arcuata, 11.7.2017, location Zakot

Slika 6. Hlorotične pjege na lišču kao rezultat prehrane adulta i ličinki C. arcuata, 11.7.2017., lokacija Zakot

after the first record, this invasive bug was present from the easternmost parts of Croatia, where its population reached huge numbers, all the way to the central part of the country where only scattered foci were discovered in the following years (Franjević et al., 2016). The northern border of the forest, where the bug was found in Slovenia, is formed by a railway line leading from the Balkan region to Central Europe. The close proximity of the Zakot site from the find in Croatia suggests that the bug spread naturally from Croatia to Slovenia, but since the site of the find is also near the railway line, it is also plausible that it was introduced from the heavily infested southern regions of the Balkans via rail transport.

In Slovenia, as well as other European countries, it will be important to focus our attention on the very probable qu- 
ick spread of the new oak pest in the near future and asses its potential negative impact on oak health status in urban areas and forests.

\section{ACKNOWLEDGEMENTS ZAHVALA}

The work was supported by research programs P4-0059 (M.J.) and P4-0107 (D.J.) financed by the Slovenian Research Agency and the Ministry for Agriculture, Forestry and Food of the Republic of Slovenia (D.J.).

\section{REFERENCES}

\section{LITERATURA}

- Baker, G.T., R.L. Brown, 1994: Chorionic fine structure of the egg of the oak tinged, Corythucha arcuata (Say) (Hemiptera: Tingidae). Proc. Entomol. Soc. Wash., 96(1):70-73

- Bernardinelli, I., P. Zandigiacomo, 2000: Prima segnalazione di Corythucha arcuata (Say) (Heteroptera, Tingidae) in Europa. Informatore Fitopatologico, 50: 47-49

- Bernardinelli, I., 2000: Potential host plants of Cotythucha arcuata (Het.: Tingidae) in Europe: a laboratory study. Journal of Applied Entomology, 130 (9-10): 480-484

- Connell, W.A., J.H. Beacher, 1947: Life history and control of the oak lace bug. Bulletin of the University of Delaware Agricultural Experiment Station. No. 265, pp. 28.

- Dioli, P., I. G. Forini, M. Moretti, M. Salvetti, 2007: Note sulla distribuzione di Corythucha arcuata (Insecta, Heteroptera, Tingidae) in Cantone Ticino (Svizzera), Valtellina e alto Lario (Lombardia, Italia). Il Naturalista Valtellinese, 18: 59-68

- Dobreva, M., N. Simov, G. Georgiev, P. Mirchev, M. Georgieva, 2013: First Record of Corythucha arcuata (Say) (Heteroptera: Tingidae) on the Balkan Peninsula. Acta zool. Bulg., 65(3): 409412
- Drake, C.J., F.A. Ruhoff, 1965: Lacebugs of the world - A catalog (Hemiptera: Tingidae). Smithsonian Institution, United States National Museum, Washington D.C., 141-142.

- Drew, W. A., D. C. Arnold, 1977: Tingoidea of Oklahoma (Hemiptera). Proceedings of the Oklahoma Academy of Science, 57: 29-31

- Forster, B., Giacalone, I., Moretti, M., Diolt, P., B. Wermelinger, 2005: Die amerikanische Eichennetzwanze Corythucha arcuata (Say) (Heteroptera, Tingidae) hat die Südschweiz erreicht. Bulletin de la Société Entomologique Suisse, 78: 317-323

- Csóka, G., A. Hirka, M. Somlyai, 2013: A tölgy csipkéspoloska (Corythuca arcuata Say, 1832 - Hemiptera, Tingidae) elsô észlelése Magyarországon. Növényvédelem, 49(7): 293-296

- Franjević, M., M. Pernek, D. Posarić., D. Banović, B. Hrašovec, 2016: Rapid spread and first data on damage levels and life cycle of Corythucha arcuata (Heteroptera, Tingidae) in Croatia. 2nd Croatian Symposium on invasive species - with international participation, Zagreb, Croatia, 21 - 22 November 2016, Book of Abstracts: 48

- Hrašovec, B., D. Posarić, I. Lukić, M. Pernek, 2013: Prvi nalaz hrastove mrežaste stjenice (Corythucha arcuata) u Hrvatskoj. Šumarski list, 9-10: 499-503

- Mutun, S., 2003: First report of the oak lace bug, Corythucha arcuata (Say, 1832) (Heteroptera: Tingidae) from Bolu, Turkey. Israel Journal of Zoology, 33: 263-268

- Mutun, S., Z. Ceyhan, C. Sözen, 2009: Invasion by the oak lacebug, Corythucha arcuata (Say) (Heteroptera: Tingidae), in Turkey. Turkish Journal of Zoology, 49(4): 323-324

- Osborn, H., C. J. Drake, 1917: Notes on American Tingidae with descriptions of new species. The Ohio Journal of Science, 17(8): 295-307

- Pap, P., M. Drekić, L. Poljaković-Pajnik, M. Marković, V. Vasić, 2015: Monitoring zdravstvenog stanja šuma na teritoriji Vojvodine u 2015. godini. Topola 195/196: 117-133

- Rabitsch, W., 2008: Alien True Bugs of Europe (Insecta: Hemiptera: Heteroptera). Zootaxa, 1827: 1-44

\section{SAŽETAK}

O nalazu hrastove mrežaste stjenice (Corythucha arcuata) u parku dvorca Lužnica kod Zaprešića, Hrvatska, 6 km od slovenske granice, obavijestio nas je prof. Boris Hrašovec sa Šumarskog fakulteta Sveučilišta u Zagrebu u jesen 2016. godine. 17. 11. 2016 obavili smo potragu za štetnikom na sedam lokacijama u jugoistočnoj Sloveniji (Mokrice, Obrežje, Rigonce, Dobova, Mostec, Zakot i Bukošek). Pričvršćeno i djelomično zeleno lišće, kao i otpalo lišće Quercus robur je bilo na terenu pomno pregledano i sumnjivi uzorci su stavljeni u plastične vrećice i donijeti u laboratorij za daljnju analizu. Morfološka identifikacija je provedena na uzorku jajnih grupa na donjoj strani lišća i svlakova ličinki (exuviae) koje su bile prisutni na otpalom lišću Q. robur. Izvršeno je mjerenje broja jaja u 9 jajnih grupa i dužina i širina 30 jajnih čahura. Jajne ljuske (čahure) i svlakovi ličinaka na otpalom lišću Quercus robur bile su na pretraženom području nađene samo u hrastovoj šumi kod sela Zakot u blizini

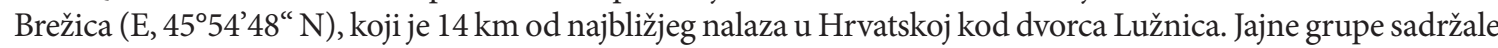
su od 12 do 61 jajnih čahura. Jajne čahure su bile vretenastog oblika i crna s apikalnim otvorom i rubnim zadebeljenjem, duge $560 \mu \mathrm{m}(475-596 \mu \mathrm{m})$ i široke $196 \mu \mathrm{m}(183-196 \mu \mathrm{m})$. Ličinke su bile uglavnom tamne sa prozirnim žućkastim dijelovima na obje strane tijela. Imale su brojne bodlje. Brojne katranasto crne mrlje izmeta (faeces) hrastove mrežaste stjenice nalazile su se ravnomjerno na donjoj površini hrastovog lišća na kojem su bile prisutne jajne čahure i svlakovi ličinki. C. arcuata najvjerovatnije se proširila u Sloveniju iz Hrvatske, gdje je bila opažena kod dvorca Lužnica, ili kao autostoper sa željezničkom transportom, jer sjevernu granicu šume kod sela Zakot predstavlja željeznička pruga koja vodi od balkanske regije prema srednjoj Europi. U početku srpnja 2017. ustanovili smo namnoženje C. arcuata na lokaciji prvog nalaza i širjenje vrste na područje Krakovske hrastove šume, udaljeno $17 \mathrm{~km}$ zračne linije od sela Zakot. 